\section{Ensidig fordømmelse av Israel}

Mads Gilbert og Erik Fosse hevder i Tidsskriftet nr. 24/2009 at øyenvitnenes politiske farge var uvesentlig under krigen i Gaza (1). De tar Tidsskriftets redaksjon og Trond Markestad i forsvar og fremfører beskrivelser av den humanitære situasjonen sammen med nok et partsinnlegg om konflikten.

Objektivt? Hamas har styrt Gaza siden 2007. De støttes militært av Iran, som ønsker å tilintetgjøre Israel. Det er ikke bare Israel som truer pressefriheten i Gaza (2). Palestinske journalister har søkt asyl i Norge etter forfølgelser og trusler fra Hamas (3). Amnesty International rapporterer at Hamas torturerer og dreper sine palestinske motstandere i Gaza, og omfanget økte i forbindelse med Gaza-krigen. Pasienter ble likvidert av Hamas. Også ved Shifasykehuset der Gilbert og Fosse arbeidet, ble pasienter skutt i sengene (4).

500 mennesker ble drept og ca. 8000 skadet i selvmordsaksjoner inne i Israel i årene 2000-07, mange utført av Hamas (5). Antallet selvmordsaksjoner er redusert betydelig de siste årene gjennom sikringstiltak fra israelsk side, blant annet streng grensekontroll. Gaza har også grense mot Egypt, som deltar aktivt i blokaden, selv om mediene har fokusert lite på dette. Egypterne ønsker minst mulig befatning med Iran-støttet islamisme i området.

I 2008 ble 1750 Hamas-raketter sendt innover israelsk område, og siden 2001 er 15 israelere drept i disse angrepene. Palestinere brukes som levende skjold, mens israelske menn, kvinner og barn løper i tilfluktsrommene flere ganger daglig. Gilbert sammenlikner disse angrepene med norsk motstandskamp under den annen verdenskrig (6). Amnesty International har definert selvmords- og rakettangrepene som overgrep mot både palestinsk og israelsk sivilbefolkning og fordømmer angrepene som kriminalitet mot menneskeheten og mot internasjonal lov (7). Israel frykter at Iran skal forsyne Hamas med langtrekkende og mer ødeleggende raketter, og tar på alvor at Hamas går inn for destruksjon av Israel gjennom hellig krig.

Genève-konvensjonen, Folkeretten og menneskerettighetene brytes systematisk og med overlegg i kampen mot staten Israel. Den ensidige fordømmelsen av Israel er ikke bare ulogisk, men også lite tjenlig for å få til en varig fredsløsning i området. Også redaksjonen av fagtidsskriftet og lederen for etikkrådet har et ansvar i denne sammenheng.

\section{Ragnvald B. Petersen \\ Sandnes \\ Litteratur \\ 1. Fosse J, Gilbert M. Objektivt i Gaza. Tidsskr Nor Legeforen 2009; 129: 2629-30.}

2. The UN Refugee Agency. Freedom of the Press 2008 - Israeli-occupied territories/Palestinian authority. www.unhcr.org/refworld/country., FREEHOU, .PSE, 4871 f60ec, 0 .html (6.4.2010).

3. Journalisten. Tre palestinske journalister i asylmottak. www.journalisten.no/story/48011 (6.4.2010).

4. Amnesty International. Palestinian Authority: Hamas' deadly campaign in the shadow of the war in Gaza. www.amnesty.org/en/library/asset/ MDE21/001/2009/en/9f210586-f762-11dd-8fd7f57af21896e1/mde210012009en.html (6.4.2010).

5. Israel Ministry of Foreign Affairs. Victims of Palestinian Violence and Terrorism since September 2000. www.mfa.gov.il/MFA/Terrorism-+Obstacle +to+Peace/Palestinian+terror+since+2000/ Victims+of+Palestinian+Violence+and+Terrorism +sinc.htm (6.4.2010)

6. NRK Nett-TV. Dagsrevyen 31.12.2008. www.nrk.no/nett-tv/indeks/154876/ (6.4.2010)

7. Amnesty International. Palestinian Authority: Hamas must stop targeting of civilians. www.amnesty.org/en/library/asset/MDE21/006/ 2006/en/980dd689-d462-11dd-8743-

d305bea2b2c7/mde210062006en.html (6.4.2010).

\section{En misinformerende anmeldelse}

I en anmeldelse af Walter Kraus' bog Mobilstråling i Tidsskriftet nr. 23/2009 misinformerede Arnt Inge Vistnes om indholdet, fordi han kun forholdt sig til elektromagnetiske felter og ikke til tidens stigende mikrobølgebestråling (1).

Modulerede og pulserende elektromagnetiske bølger eller stråler, der bruges ved UMTS (Universal Mobile Telecommunications System) og trådløse mobile bredbånd som WiFi (Wireless Fidelity) og Wlan (Wireless Local Area Network) blev forbigået i tavshed. Anmeldelsen blev desværre kun fulgt op af henvisninger til litteratur, der omtaler forskning med elektromagnetiske felter.

Der er så megen forskning, som frasorteres i disse år, og som det er vigtigt at nævne, fordi børn er en sårbar gruppe. I over 60 år har russerne foretaget dyre- og vævsforskning med elektromagnetiske felter og stråler, og allerede i 1965 meldte de ud om negative biologiske følgevirkninger af mikrobølger (2). Den nu 84-årige professor Yuri Grigoriev er stadig forskningsaktiv, og han har blandt andet ud fra forsøg med eksponerede dyreæg (3), advaret imod mobilbrug hos børn, for jo yngre væv der eksponeres, jo større er risikoen for vævsskader $(4,5)$.

Rusland, Kina og Italien har lavere grænseværdier end de grænseværdier, som den selvsupplerende kommission ICNIRP (International Commission on Non-Ionizing Radiation Protection) har fastsat, fordi kommissionens grænseværdier kun tager højde for en akut termal skadevirkning. Vistnes vurderer imidlertid gældende standarder som tilstrækkelige. Han omtaler slet ikke mulige non-termale biologiske skadevirkninger, selv om de er veldokumenteret (6).

I Ægypten er der blevet foretaget ekspo- neringsforsøg med mikrobølger på fostre og nyfødte børn, som fik hjerteforstyrrelser (7), og i Grækenland er mus blevet eksponeret i flere generationer, indtil de blev sterile (8). Disse resultater er meget vigtige, fordi børn er en udsat gruppe, og fordi vi mennesker får sværere og sværere ved at reproducere os selv. Børn kan ikke beskytte sig selv imod en ukendt og usynlig mobilstrålingsfare, og selvfølgelig skal vi alle informeres om denne stigende trådløse forureningstrussel, som Vistnes fejede væk med et pennestrøg.

\section{Bente-Ingrid Bruun}

Danmark

\section{Litteratur}

1. Vistnes Al. Tendensiøst om stråling. Tidsskr Nor Legeforen 2009; 130: 2510-11.

2. Presman AS. The action of microwaves on living organismes biological structures. Soviet Physics Uspekhi 1965; 8: 463-88.

3. Grigoriev J. Biological effects of mobile phone electromagnetic field on chick embryo lrisk assessment using the mortality rate). Radiats Biol Radioecol 2003; 43: 541-3.

4. Bruun BI. De trådløse samfund - myter \& fakta. Bilag C. København: Books on Demand, 2009.

Center for Electromagnetic Safety. www.tesla.ru/ english/protection/expert.html (26.3.2010).

6. Belyaev I. Non-thermal biological effects of microwaves: current knowledge, further perspective and urgent needs. www.cost281.org/download.php?fid $=714(26.3 .2010)$.

7. Rezk A, Abdulquawi K, Mustafa RM et al. Fetal and neonatal responses following maternal exposure to mobile phones. Saudi Med J 2008; 29: 218-23.

8. Magras IN, Xenos TD. RF radiation-induced changes in the prenatal development of mice. Bioelectromagnetics 1997; 18: 455-61.

\section{Dr. Hyde?}

I Tidsskriftet nr. 6/2010 undrer Robin Holtedahl seg over at jeg har valgt å bruke navneparet dr. Jekyll og dr. Hyde om to legeskikkelser (1). Han henviser til et intervju i Tidsskriftet nr. 24/2009 (2) og boken Penger og verdier $i$ helsetjenesten (3). Holtedahl skriver: «Om det skyldes uvitenhet fra forfatterens side er uklart, men uansett vil lesere av Robert Louis Stevenson vite at dr. Jekylls onde alter ego het mr. Hyde, og slett ikke var lege» (1). Kapitlet det er snakk om, Penger i sykehus - dr. Jekylls lidelse (4), åpner med følgende sitat: «Det var i moralen, i min egen personlighet, jeg lærte at mennesket er gjennomgående og opprinnelig dobbelt. Av de to naturene som sloss om herredømmet i min egen bevissthet, forsto jeg, selv om jeg med rette kunne hevde at jeg var enten det ene eller andre, at jeg faktisk dypest sett var begge.» Sitatet er fra Stevensons verk Doktor Jekyll og herr Hyde (5) som er referert i kapitlet. Min tekst er bygd opp omkring en dialog mellom to fiktive klinikere som jeg har kalt dr. Jekyll og dr. Hyde. Navnevalget bunner ikke i uvitenhet. Jeg valgte dr. Hyde og ikke herr Hyde, eller det engelske mr. Hyde, fordi teksten dreier seg om to leger. De to 